\title{
Probiotic technological and functional characteristics of Lactobacillus strains isolated from chicken gut
}

\author{
[Características tecnológicas e funcionais de linhagens de Lactobacillus isoladas do \\ trato gastrointestinal de frangos]

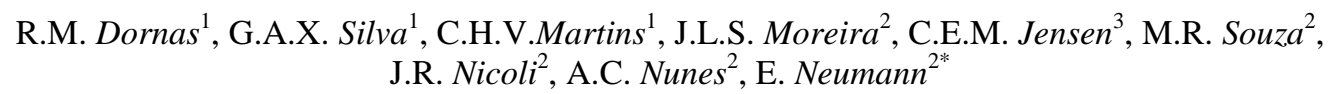 \\ ${ }^{1}$ Centro Universitário Newton Paiva - Belo Horizonte, MG \\ ${ }^{2}$ Universidade Federal de Minas Gerais - Belo Horizonte, MG \\ ${ }^{3}$ Universidade Federal de São João Del Rey - São João Del Rey, MG
}

\begin{abstract}
Lactobacillus spp. isolated from different portions of chickens' gastrointestinal tract were evaluated concerning their ability to survive in a water-in-oil (W/0) emulsion containing sesame and sunflower oil. After sixty days of emulsion storage under refrigeration, three of five strains tested survived in number equal to or higher than $10^{6} \mathrm{cfu} / \mathrm{g}$. Lactobacillus reuteri $2 \mathrm{M} 14 \mathrm{C}$, which presented the highest survival in $\mathrm{W} / \mathrm{O}$ emulsion $\left(10^{7} \mathrm{cfu} / \mathrm{g}\right)$, was tested for its capacity to resist throughout the passage through gnotobiotic mice gastrointestinal tract and for the ability to stimulate murine peritoneal macrophages phagocytosis. This strain remained at a number above $10^{9} \mathrm{cfu} / \mathrm{g}$ feces during ten days of monoassociation, and monoassociated mice showed phagocytic activity significantly greater than the germ-free controls $(\mathrm{P}<0.05)$. The results suggest that the formulation can be used to incorporate viable Lactobacillus spp. cells in animal feed. Moreover, the results suggest that L. reuteri $2 \mathrm{M} 14 \mathrm{C}$ is a strong candidate to be incorporated in probiotic formulations for use in chicken.
\end{abstract}

Keywords: chicken, probiotic, Lactobacillus, emulsion, phagocytosis

\section{RESUMO}

Lactobacillus spp. isolados de diferentes porções do trato gastrintestinal de frangos foram testados quanto à capacidade de se manterem viáveis em uma emulsão águalóleo (A/O) contendo óleos de gergelim e de girassol. Após sessenta dias de estocagem sob refrigeração, três de cinco linhagens testadas sobreviveram em concentração igual ou superior a $10^{6} \mathrm{UFC} / \mathrm{g}$. Lactobacillus reuteri $2 \mathrm{M} 14 \mathrm{C}$, que apresentou maior capacidade de sobrevivência na emulsão desenvolvida (10 $\left.{ }^{7} \mathrm{UFC} / \mathrm{g}\right)$, foi testado quanto à sua capacidade de sobreviver às condições do trato gastrintestinal in vivo em camundongos gnotobióticos. Após dez dias de monoassociação com L. reuteri 2M14C, foi testada também a capacidade de estimulação da atividade fagocítica de macrófagos peritoneais. A linhagem permaneceu em número superior a $10^{9} \mathrm{UFC} / \mathrm{g}$ de conteúdo fecal durante os dez dias de monoassociação, e os camundongos monoassociados apresentaram atividade fagocítica maior $(P<0,05)$ que a do grupo controle isento de germe. Os resultados sugerem que a formulação proposta é capaz de manter a viabilidade de células de lactobacilos para adição em ração animal, necessitando, no entanto, de um acompanhamento dessa viabilidade por tempo maior de estocagem. Além disso, os resultados demonstram que Lactobacillus reuteri 2M14C é um forte candidato a ser adicionado em formulações probióticas para uso em frangos.

Palavras-chave: frango, probióticos, Lactobacillus, emulsão, fagocitose

Recebido em 18 de março de 2013

Aceito em 20 de agosto de 2013

*Autor para correspondência (corresponding author)

E-mail: eneumann@icb.ufmg.br 


\section{INTRODUCTION}

Probiotics are live microorganisms which when administered in adequate amount confer health benefits to the host (FAO/WHO, 2001). These beneficial effects include: immunomodulation, balance of colonic microbiota, anticarcinogenic effect, hypocholesterolemic effect, and antagonism against pathogens (Miyazaki et al., 2010; Williams, 2010).

Scientific research supports the role of probiotics as effective alternatives to the use of antimicrobial growth promoters in animal nutrition (Mountzouris et al., 2010), and the beneficial effects of probiotics on broilers have been reported (Higgins et al., 2008; Eckert et al., 2010). However, the screening of appropriate microorganisms must include technological and functional criteria in order to achieve probiotic efficacy. An essential feature for a probiotic is its ability to survive in sufficient number in the host gastrointestinal tract (Pitino et al., 2010). Furthermore, this strain must be able to resist the stressing physicochemical conditions of the production process, to survive during the longterm storage period of the product that will carry it and to be produced in large quantities (Ross et al., 2005). Also, a new candidate for use as a probiotic must not have any proven functional characteristic which cannot be modified by the production process.

Several attempts have been made to develop products containing probiotic microorganisms such as Lactobacillus and Bifidobacterium species for animal and human consumption (Williams, 2010). However, studies indicate that some probiotics may not survive and retain their activity in market preparations or in the host gastrointestinal tract, which limits their practical use in foods and pharmaceutical or food supplements (Stadler e Viernstein, 2003; Corcoran et al., 2004). In this regard, the microencapsulation process of microbial cells with potential probiotic characteristics has been investigated in order to increase the viability of the microorganisms to ensure their passage through the host's gastrointestinal tract (Sultana et al., 2000). Microencapsulation consists of bioactive materials and/or cells involved in polymeric ultrafine semi-permeable membranes to protect them from environmental damage without avoiding the passage of essential substances through the microcapsule (Orive et al., 2004). Sesame oil (Sesamum indicum L.) has long been used for human consumption and it was demonstrated that encapsulation with artificial sesame oil emulsions exert a significant protective effect on lactic acid bacteria in high acid gastric and bile salt simulated conditions (Hou et al., 2003).

In our laboratory, Lactobacillus strains previously isolated from chicken gastrointestinal tracts have demonstrated probiotic characteristics (Souza et al., 2007). Thus, one of the goals of this work was to evaluate if some of these Lactobacillus strains would be able to survive during production and storage in a water-in-oil (W/0) emulsion that has sesame oil as its encapsulating ingredient. In addition, it was evaluated if $L$. reuteri $2 \mathrm{M} 14 \mathrm{C}$, a strain that had the best survival capacity in the developed formulation, could survive at high population level in the gastrointestinal tract of monoassociated mice and stimulate their mononuclear phagocytic system. These characteristics could define this strain as a good probiotic candidate for chicken.

\section{MATERIAL AND METHODS}

Germfree Swiss/NIH mice (Taconic, Germantown, NY, USA), 21-23 days old and of both genders were maintained at the Gnotobiology Laboratory of the Universidade Federal de Minas Gerais, Belo Horizonte, MG, Brazil, according to the procedures described by Pleasants (1974). All experimental procedures were carried out according to the standards set forth in the "Colégio Brasileiro de Experimentação Animal" rules (COBEA, 2006). The study was approved by the Ethics Committee in Animal Experimentation of the Universidade Federal de Minas Gerais (CETEA/UFMG, protocol $\left.n^{\circ} .203 / 2009\right)$.

Lactobacillus strains used in this study were isolated from the gastrointestinal tract of free-range chickens and identified through the PCR-ARDRA methodology of intergenic spacers of $16 \mathrm{~S}-23 \mathrm{~S}$ rRNA (Mota et al., 2006; Souza et al., 2007). Five strains were used, L. reuteri $2 \mathrm{M} 14 \mathrm{C}, L$. acidophilus 4M14E, L. vaginalis 5M14E, L. salivarius 4C14C and $L$. salivarius $5 \mathrm{C} 14 \mathrm{C}$. They were activated twice in MRS broth (De Man, Rogosa and Sharpe, Difco, Sparks, MD, USA) at $37^{\circ} \mathrm{C}$ for $18 \mathrm{~h}$. Fifty milliliters of each active culture were centrifuged at 2000xg and washed with an equal volume of PBS (buffered saline solution, $\mathrm{pH}$ 7.3) two fold. After washing, each culture was ressuspended in reconstituted nonfat dry milk 10\% (NFDM 10\%) in order to obtain a suspension with $10^{10}$ colony forming units $((\mathrm{cfu}) / \mathrm{ml})$ of lactobacilli that were incorporated into the emulsion. 
From a previous standardization, a stable emulsion containing viable cells from each isolate was obtained with $1.06 \%$ of commercial sesame oil, $53.48 \%$ of commercial sunflower oil, $10.91 \%$ of glyceril monostearate, $6.36 \%$ cetostearylic acid and $28.19 \mathrm{~mL}$ of $10 \%$ NFDM. The total amount of sesame oil was heated at $70^{\circ} \mathrm{C}$ and after this time, sunflower oil, glyceril monostearate and cetostearylic acid were added and heated at $70^{\circ} \mathrm{C}$ until the ingredients were completely mixed. This mixture was then cooled to $40^{\circ} \mathrm{C}$. Adequate volume of $10 \%$ NFDM containing Lactobacillus spp. cells was heated at $40^{\circ} \mathrm{C}$ in a water bath and was slowly incorporated into the flask containing the other ingredients, followed by mechanical agitation (630rpm, homogenizer MA102/Plus, Marconi, São Paulo, SP, Brazil) during ten minutes. The formation of sesame oil micelles at the end of the emulsification process was confirmed by optical microscopic examination of a tenfold dilution of each emulsion.

Strains viability in emulsion was tested $24 \mathrm{~h}$ after preparation and after sixty days of storage under refrigeration $\left(8^{\circ} \mathrm{C}\right)$. As control, the strains were ressuspended in 10\% NFDM and stored under refrigeration. Ten grams of each sample were serially diluted in $0.1 \%$ peptone solution plus Tween 80 and poured on MRS agar (De Man, Rogosa and Sharpe, Difco, USA). The results, expressed as cfu/g of emulsion were calculated from MRS agar after $48 \mathrm{~h}$ incubation at $37^{\circ} \mathrm{C}$ in aerobic conditions.

Lactobacillus reuteri 2M14C was grown in MRS broth (De Man, Rogosa and Sharpe, Difco, USA) for $18 \mathrm{~h}$ at $37^{\circ} \mathrm{C}$. This activated culture was centrifuged $\left(2000 \mathrm{xg}, 10 \mathrm{~min}, 4^{\circ} \mathrm{C}\right)$ and resuspended in PBS in order to obtain $10^{9} \mathrm{cfu} / \mathrm{mL}$. One hundred microliters of this suspension were inoculated intragastrically into germ-free mice. The control group received PBS. The success of monoassociation was checked by investigating the number of cfu/gram of feces during ten days.

Peritoneal macrophages from monoassociated and germ-free mice were obtained as follows: the peritoneal cavity was washed with approximately eight $\mathrm{ml}$ of RPMI 1640 medium (Sigma Chemicals Co., St. Louis, MO, USA); this suspension was centrifuged (1000xg, 10min), and the recovered cells were resuspended in medium RPMI 1640 at a final concentration of $1 \times 10^{5}$ cells $/ \mathrm{mL}$. The phagocytosis test was done as described by Giaimis et al. (1992). Briefly, peritoneal cells were plated in 24-well plates with a round glass slide at the bottom for $2 \mathrm{~h}$ at $37^{\circ} \mathrm{C}$ in a $5 \% \mathrm{CO}_{2}$ incubator. After this time, the medium was removed and $100 \mu \mathrm{L}$ of an autoclaved Saccharomyces boulardii suspension containing $10^{8} \mathrm{cfu} / \mathrm{ml}$ was added to each well following incubation for $1 \mathrm{~h}$ at $37^{\circ} \mathrm{C}$ in a $5 \% \mathrm{CO}_{2}$ incubator. The glass slides were then covered with $1 \%$ tannic acid before staining with MayGrumwald-Giemsa. Two hundred cells per slide were evaluated and attached yeast (violet) and internalized yeasts (pink) were enumerated separately. The results were expressed as number of attached and internalized yeast per macrophage.

The data were statistically analyzed using the Student's $t$-test at a probability level of 0.05 . Statistical analyses were performed using the Sigma Stat program (Jandel Scientific Software, version 1.0, San Rafael, CA, USA).

\section{RESULTS AND DISCUSSION}

Sesame oil heated at $70^{\circ} \mathrm{C}$ before mixing with other emulsion components generated spherical oil bodies with a diameter sufficient to entrap lactobacillus cells (Figure 1). Sesame oil must be heated at $70^{\circ} \mathrm{C}$ before mixing with other emulsion components in order to generate spherical oil bodies with a diameter sufficient to entrap lactobacillus cells, in accordance with results by Hou et al. (2003). Heating sesame oil at $40^{\circ} \mathrm{C}$ before mixing was unable to generate micelles of sufficient size to cover lactobacilli cells and the viability of one strain tested ( $L$. reuteri $2 \mathrm{M} 14 \mathrm{C}$ ) in emulsion prepared with sesame oil heated at $70^{\circ} \mathrm{C}$ was higher than in an emulsion of sesame oil heated at $40^{\circ} \mathrm{C}$ (data not shown). Both sesame and sunflower oil are food grade ingredients and have been utilized as emulsion components and other formulation systems to carry genes, antigenic proteins, drugs and microorganisms (Sriamornsak et al., 2004; Nam et al., 2009; Ying et al., 2010). 


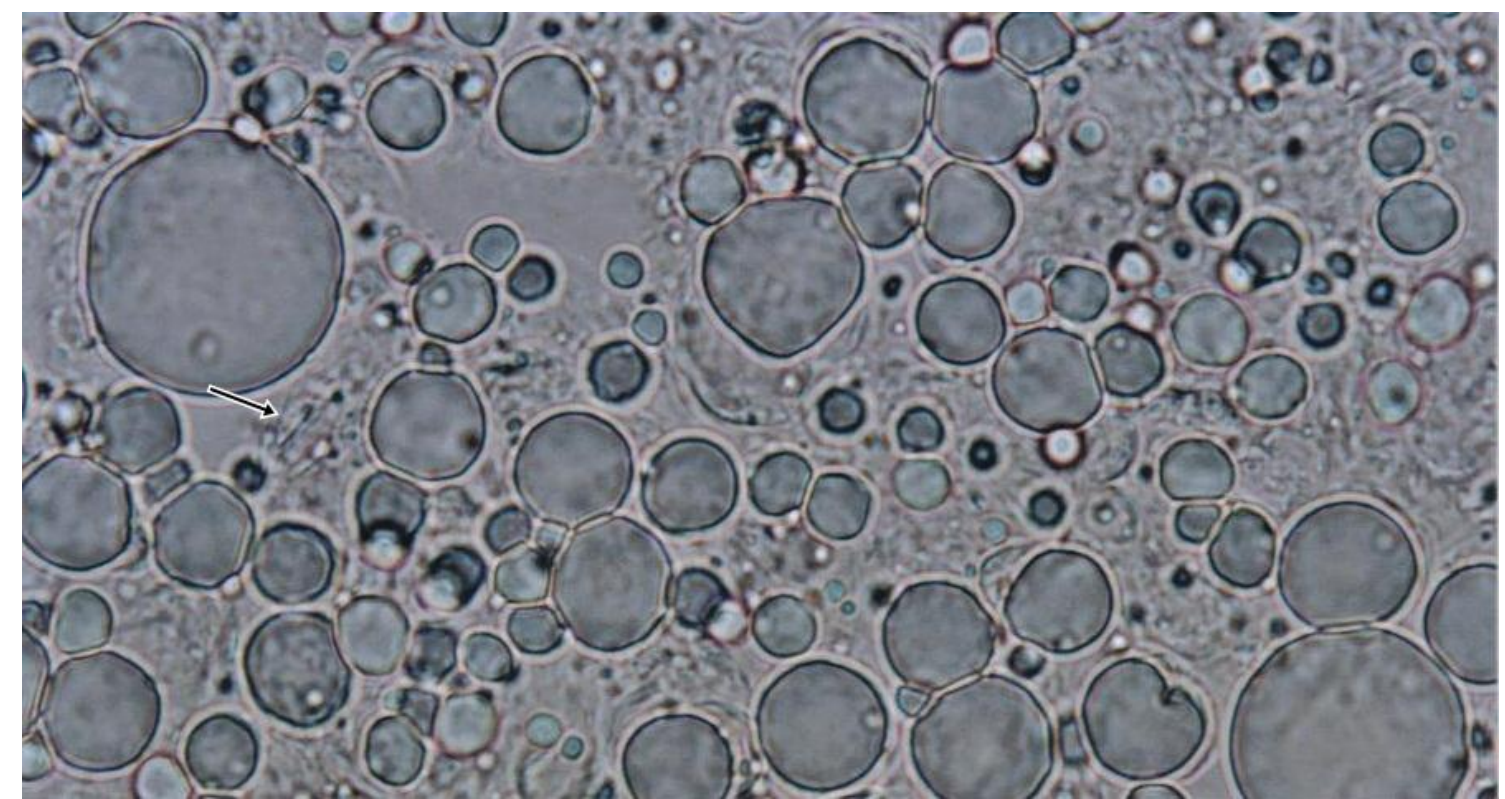

Figure 1. Light microscopy of W/O sesame oil emulsion containing Lactobacillus reuteri 2M14C cells. Arrow shows a lactobacillus cell. Original magnification: $100 \mathrm{X}$.

The survival of all lactobacilli strains in the emulsion at the first day was similar to the survival in $10 \%$ NFDM, used as control (Figure 2). After sixty days of emulsion storage under refrigeration, the viability of cells maintained in emulsion was higher than in control, except for L. salivarius 4C14C, which survived slightly better in NFDM than in emulsion and three among five strains tested survived in number equal to or higher than $10^{6} \mathrm{cfu} / \mathrm{g}$. The survival of strains tested herein are similar to that observed by Hou et al. (2003) and Chandramouli et al. (2004) who observed the maintenance of lactobacillus viability in artificial sesame oil emulsion and alginic acid, respectively. Lactobacillus strains showed different degrees of sensitivity to formulation storage at refrigeration for sixty days, which could be explained by eventual metabolic and morphologic differences between them. Among the strains tested, the less sensitive was $L$. reuteri 2M14C, followed by $L$. salivarius $5 \mathrm{C} 14 \mathrm{C}$ and $L$. vaginalis $5 \mathrm{M} 14 \mathrm{E}$, in this order. These strains survived in number not inferior to $10^{6} \mathrm{cfu} / \mathrm{g}$ of emulsion at the end of storage time.

Resistance to stressing gastrointestinal conditions is very important for probiotics to perform their beneficial effects on the host. Soon after isolation, all the strains tested herein showed high resistance to acid $\mathrm{pH}$, showing low or no reduction in the number of viable cells after $3 \mathrm{~h}$ of incubation in simulated gastric juice. Susceptibility to bile salts was variable among the five strains tested. $L$. reuteri $2 \mathrm{M} 14 \mathrm{C}$ demonstrated less inhibition after six hours of incubation in the presence of bile salts (approximately 30\%) and L. salivarius 5C14C was more strongly inhibited by the presence of bile salts (approximately 70\%) (Mota et al., 2006).

Once L. reuteri $2 \mathrm{M} 14 \mathrm{C}$ demonstrated good tolerance to gastric juice and bile salts and the best survival after sixty days in the emulsion $\left(10^{7} \mathrm{cfu} / \mathrm{g}\right)$, its resistance capacity to gastrointestinal conditions in vivo was evaluated. The use of the germfree model is quite appropriate to achieve this goal and it has been used for a long time in the selection of probiotics (Martins et al, 2012). The high fecal level of $L$. reuteri $2 \mathrm{M} 14 \mathrm{C}$ in monoassociated mice up to ten days (Figure 3 ) indicates its ability to bypass the stressing conditions of the gastrointestinal tract, one of the putative characteristics of potential probiotics (FAO/WHO, 2001). 


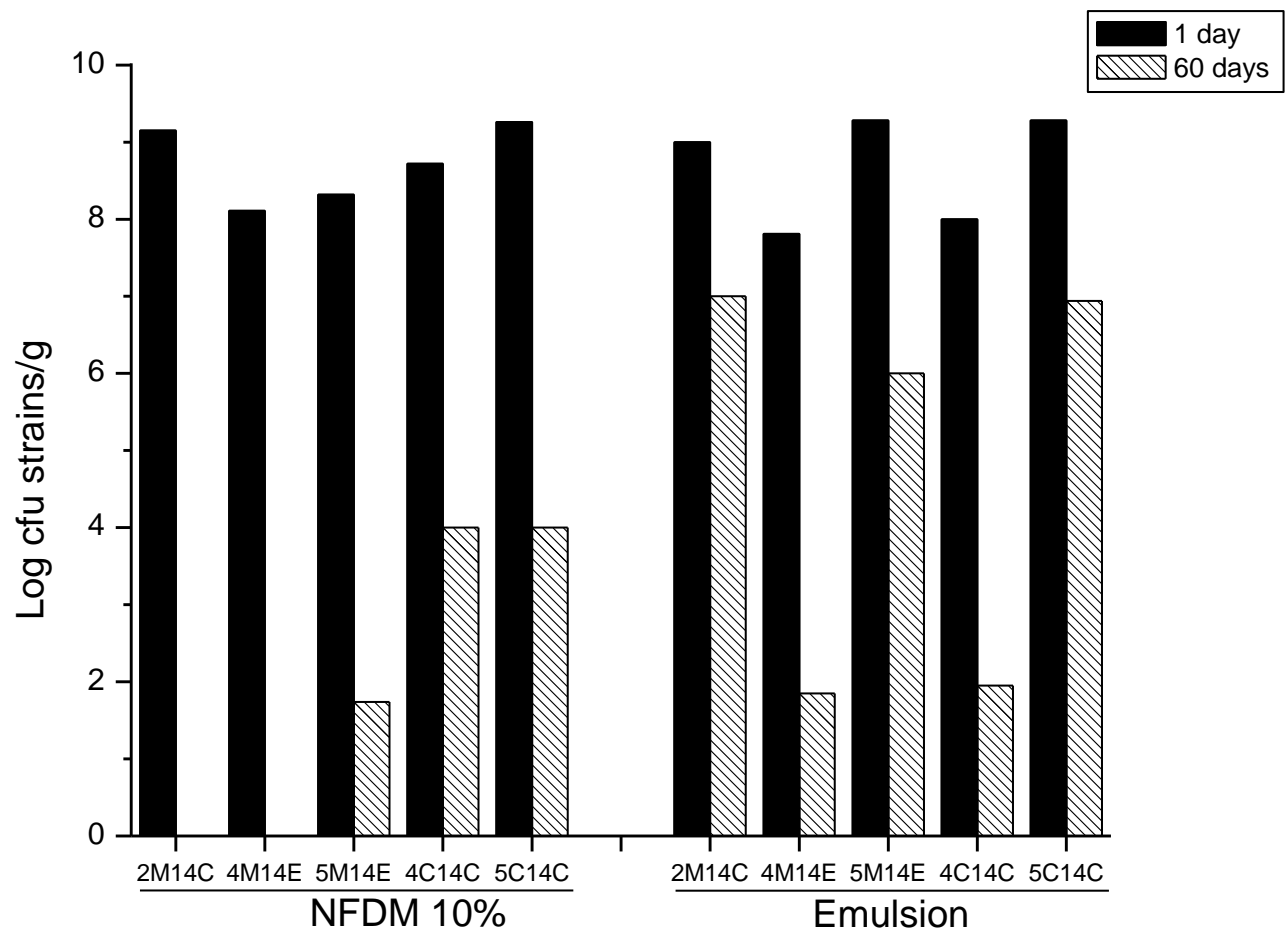

Figure 2. Survival (log cfu/g) of each Lactobacillus strain in emulsions and 10\% NFDM (control) on the first day (black bars) and after sixty days (hatched bars) of storage under refrigeration.

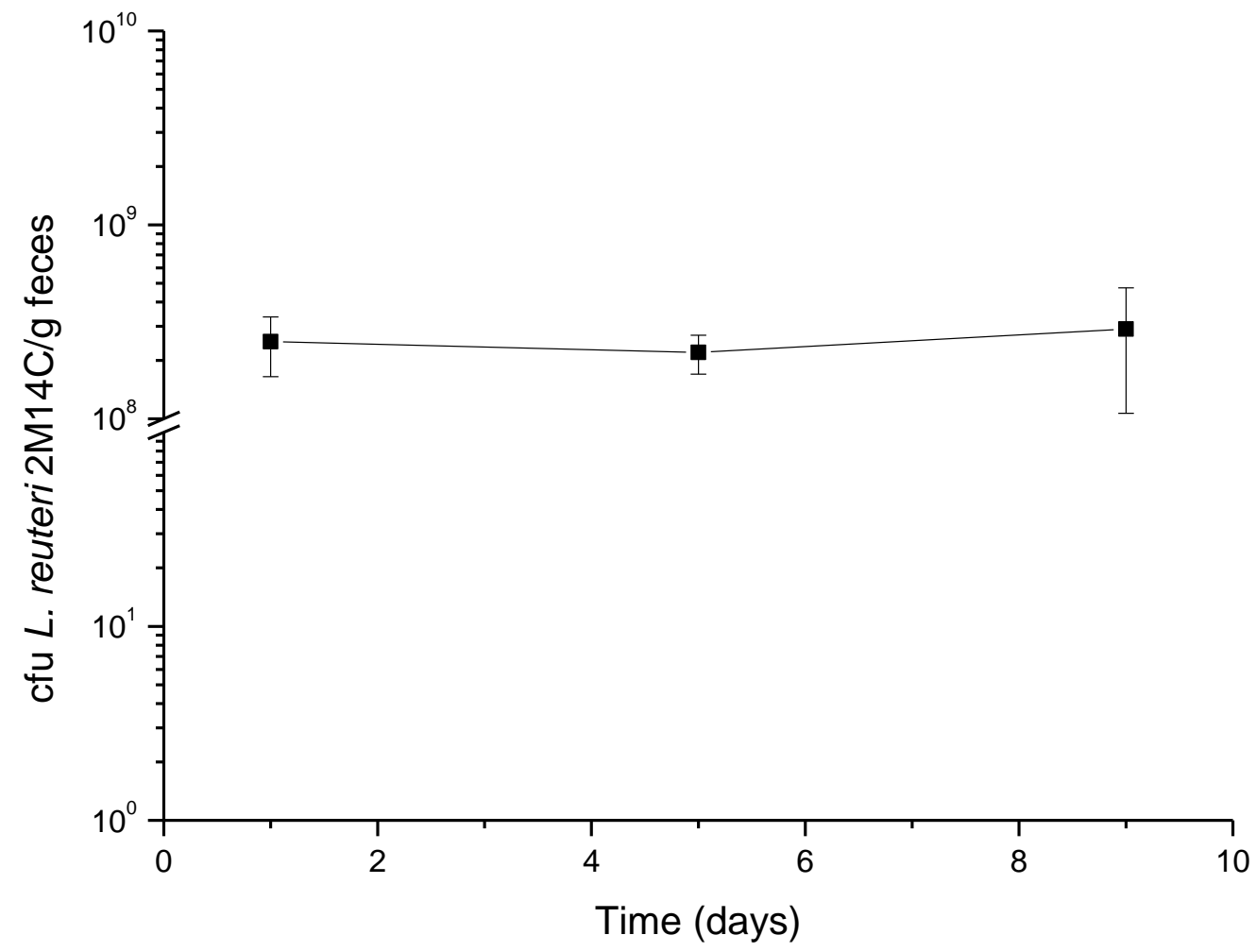

Figure 3. Number of viable Lactobacillus reuteri 2M14C cells in monoassociated mice feces. 
We demonstrated herein that oral administration of $L$. reuteri $2 \mathrm{M} 14 \mathrm{C}$ improved $(\mathrm{P}<0.05)$ the phagocytic capacity of peritoneal macrophages in mice, an innate immune defense mechanism against pathogens (Figure 4). This is a very important result since probiotics have previously been associated with the activation of innate immunity through phagocytic cells and this feature is important in resistance against infections and performance improvement of broiler chicks (Higgins et al., 2007; Higgins et al., 2008; Neumann et al., 2009).

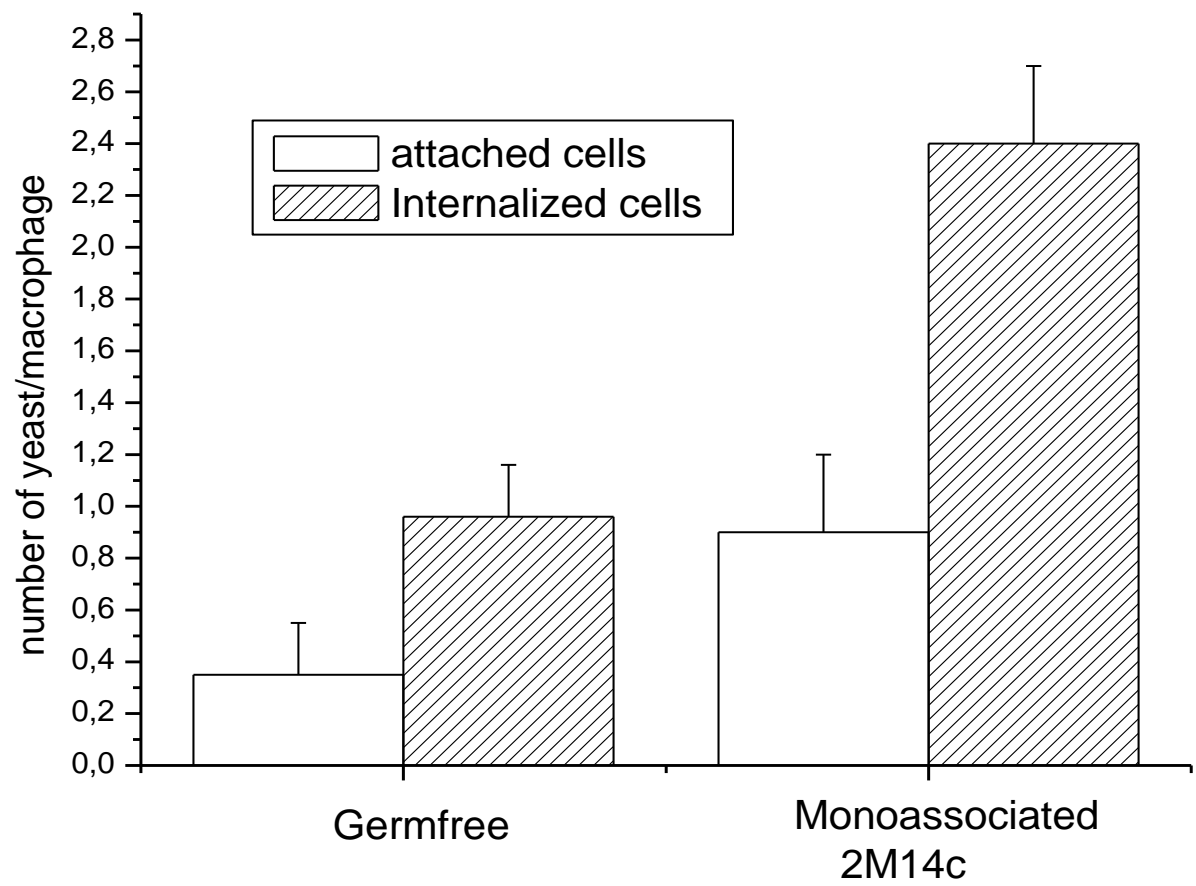

Figure 4. Number of autoclaved Saccharomyces boulardii attached on (white bars) and internalized by (hatched bars) peritoneal macrophages from germ-free mice and Lactobacillus reuteri 2M14C monoassociated mice.

\section{CONCLUSIONS}

Lactobacillus reuteri $2 \mathrm{M} 14 \mathrm{C}$ showed the best capacity to survive in emulsion, was resistant to gastric juice and bile salts, persisted in the gastrointestinal tract of monoassociated mice and improved the phagocytic capacity of peritoneal macrophages in these mice. Since this strain has these characteristics, it is suggested that it is a good candidate to be used as a probiotic for chicken, from which it was isolated. Besides, it was demonstrated that it is possible to maintain the viability of Lactobacillus species in a W/O emulsion containing sesame and sunflower oils. Thus, these ingredients might be used in formulations for the incorporation of lactobacilli in animal feed.

\section{ACKNOWLEDGMENTS}

This study was supported by grants from Conselho Nacional de Desenvolvimento Científico e Tecnológico (CNPq) and Fundação de Amparo à Pesquisa do Estado de Minas Gerais (FAPEMIG). The authors are grateful to Clelia Nunes da Silva for valuable technical help and to Antônio Mesquita Vaz for animal care.

\section{REFERENCES}

CHANDRAMOULI, V.; KAILASAPATHY, K.; PEIRIS, P.; JONES, M. An improved method of microencapsulation and its evaluation to protect Lactobacillus spp. in simulated gastric conditions. J. Microbiol. Methods, v.56, p.27-35, 2004. 
COBEA. Colégio Brasileiro de Experimentação Animal (2006). Legislação e Ética. http://www.cobea.org.br/. Accessed 01 March 2009.

CORCORAN, B.M.; ROSS, R.P.; FITZGERALD, G.F.; STANTON, C. Comparative survival of probiotic lactobacilli spray-dried in the presence of prebiotic substances. J. Appl. Microbiol., v.96, p.1024-1039, 2004.

ECKERT , N.H.; LEE, J.T.; HYATT, D. et al. Influence of probiotic administration by feed or water on growth parameters of broilers reared on medicated and nonmedicated diets. J. Appl. Poult. Res., v.19, p.59-67, 2010.

FAO/WHO. Evaluation of health and nutritional properties of probiotics in food, including powder milk with live lactic acid bacteria. Food and Agriculture Organization of the United Nations and World Health Organization Expert Consultation Report, p.1-34, 2001.

GIAIMIS, J.; LOMBARD, Y.; MAKAYAKUMBA, M. et al. A new and simple method for studying the binding and ingestion steps in the phagocytosis of yeasts. J. Immunol. Methods, v.154, p.185-193, 1992.

HIGGINS, S.E.; ERF, G.F.; HIGGINS, J.P. et al. Effect of probiotic treatment in broiler chicks on intestinal macrophage numbers and phagocytosis of Salmonella Enteritidis by abdominal exudate cells. Poul. Sci., v.86, p.2315-2321, 2007.

HIGGINS, S.E.; HIGGINS, J.P.; WOLFENDEN, A.D. et al. Evaluation of a Lactobacillus-based probiotic culture for the reduction of Salmonella Enteritidis in neonatal broiler chicks. Poult. Sci., v.87, p.27-31, 2008.

HOU, R.C.W.; LIN, M.Y.; WANG, M.C.; TZEN, J.T.C. Increase of viability of entrapped cells of Lactobacillus delbrueckii ssp. bulgaricus in artificial sesame oil emulsions. J. Dairy Sci., v.86, p.424-428, 2003.

MARTINS, F.S.; GENEROSO, S.V.; RODRIGUES, A.C.P. et al. Modelos animais gnotobióticos e convencionais para a seleção e avaliação de probióticos. In: CÉLIA, L.F. Probióticos e Prebióticos: Atualização e Prospecção. Rio de Janeiro: Editora Rubio Ltda, 2012. v.9. p.145-160.
MIYAZAKI, Y.; KAMIYA, S.; HANAWA, T. et al. Effect of probiotic bacterial strains of Lactobacillus, Bifidobacterium, and Enterococcus on enteroaggregative Escherichia coli. J. Infect. Chemother., v.16, p.10-18, 2010.

MOTA, R.M.; MOREIRA, J.L.S.; SOUZA, M.R. et al. Genetic transformation of novel isolates of chicken Lactobacillus bearing probiotic features for expression of heterologous proteins: a tool to develop live oral vaccines. BMC Biotechnol., v.6, p.2-12, 2006.

MOUNTZOURIS, K.C.; PALAMIDI, I.; ARVANITI, A. et al. Effects of probiotic inclusion levels in broiler nutrition on growth performance, nutrient digestibility, plasma immunoglobulins, and cecal microflora composition. Poult. Sci., v.89, p.58-67, 2010.

NAM, H.Y.; PARK, J.H.; KIM, K. et al. Lipidbased emulsion system as non-viral gene carriers. Arch. Pharmacol. Res., v.32, p.639-646, 2009.

NEUMANN, E.; RAMOS, M.G; SANTOS, L.M. et al. Lactobacillus delbrueckii UFV-H2b20 induces type 1 cytokine production by mouse cells in vitro and in vivo. Braz. J. Med. Biol. Res., v.42, p.358-367, 2009.

ORIVE, G.; HERNÁNDEZ, R.M.; GÁSCON, A.R. et al. History, challenges and perspectives of cell microencapsulation. Trends in Biotechnol., v.22, p.87-92, 2004.

PITINO I.; RANDAZZO, C.L.; MANDALARI,G. et al. Survival of Lactobacillus rhamnosus strains in the upper gastrointestinal tract. Food Microbiol., v.27, p.1121-1127, 2010.

PLEASANTS, J.R. Gnotobiotics. In: MELBY JR., E.C.; ALTMANN, N.H. (Eds). Handbook of Laboratory Animal Science. USA: CRC Press, 1974. p.119-174.

ROSS, R.P.; DESMOND, C.; FITZGERALD, G.F.; STANTON, C. (2005). Overcoming the technological hurdles in the development of probiotic foods. J. Appl. Microbiol., v.98, p.1410-1417, 2005.

SOUZA, M.R.; MOREIRA, J.L.; BARBOSA, F.H.F. et al. Influence of intensive and extensive breeding on lactic acid bacteria isolated from Gallus gallus domesticus ceca. Vet. Microbiol., v.120, p.142-150, 2007. 
SRIAMORNSAK, P.; THIRAWONG, N.; PUTTIPIPATKHACHORN, S. Morphology and buoyancy of oil-entrapped calcium pectinate gel beads. The AAPS Journal, v.6, p.1-6, 2004.

STADLER, M.; VIERNSTEIN, H. Optimization of a formulation containing viable lactic acid bacteria. Int. J. Pharm., v.256, p.117-122, 2003.

SULTANA, S.; GODWARD, G.; REYNOLDS, N. et al. Encapsulation of probiotic bacteria with alginate-starch and evaluation of survival in simulated gastrointestinal conditions and in yoghurt. Int. J. Food Microbiol., v.62, p.47-55, 2000.
WILLIAMS, N.T. Probiotics. Am. J. Health-Syst. Pharm., v.67, p.449-458, 2010.

YING, D.Y.; PHON, M.C.; SANGUANSRI, L. et al. (2010). Microencapsulated Lactobacillus rhamnosus GG powders: relationship of powder physical properties to probiotic survival during storage. J. Food Sci., v.75, E588-E595, 2010. 